\title{
$E_{2} \beta$ stimulates ovine uterine artery endothelial cell $\mathrm{H}_{2} \mathrm{~S}$ production in vitro by estrogen receptor-dependent upregulation of cystathionine $\beta$-synthase and cystathionine $\gamma$-lyase expression ${ }^{\dagger}$
}

\author{
Thomas J. Lechuga (D) 1,2, Qian-rong Qi ${ }^{1}$, Theresa Kim ${ }^{1}$, \\ Ronald R. Magness ${ }^{3}$ and Dong-bao Chen ${ }^{1,2, *}$
}

${ }^{1}$ Department of Obstetrics and Gynecology, University of California Irvine, Irvine, California, USA; ${ }^{2}$ Department of Pathology, University of California Irvine, Irvine, California, USA and ${ }^{3}$ Department of Obstetrics and Gynecology, Perinatal Research Vascular Center, University of South Florida, Tampa, Florida, USA

\begin{abstract}
*Correspondence: Department of Obstetrics and Gynecology, University of California Irvine, Irvine, 140 Med Surge 1, CA 92697, USA. E-mail: dongbaoc@uci.edu

†rant Support: This study was supported in part by National Institutes of Health (NIH) grants R01 HL70562 and R21 HL98746 to DBC and P01 HD38843 and R01 HL117341 to RRM. TJL was an American Heart Association (AHA) Pre-doctoral Fellow (AHA14PRE18570033). The content is solely the responsibility of the authors and does not necessarily the official views of NIH and AHA.

Edited by Dr. Romana Nowak, PhD, University of Illinois Urbana-Champaign
\end{abstract}

Received 5 October 2017; Revised 29 August 2018; Accepted 27 September 2018

\begin{abstract}
Endogenous hydrogen sulfide $\left(\mathrm{H}_{2} \mathrm{~S}\right)$ is a potent vasodilator and proangiogenic second messenger synthesized from L-cysteine by cystathionine $\beta$-synthase (CBS) and cystathionine $\gamma$-lyase (CTH). Estrogens are potent vasodilators that stimulate $\mathrm{H}_{2} \mathrm{~S}$ biosynthesis in uterine arteries (UA) in vivo; however, the underlying mechanisms are unknown. We hypothesized that estrogens stimulate $\mathrm{H}_{2} \mathrm{~S}$ biosynthesis in UA endothelial cells (UAEC) via specific estrogen receptor (ER)-dependent mechanisms. In cultured primary UAEC, treatment with estradiol-17 $\beta\left(E_{2} \beta\right)$ stimulated CBS and $\mathrm{CTH}$ mRNAs and proteins in a time- and concentration-dependent fashion. As little as $0.1 \mathrm{nM} \mathrm{E}_{2} \beta$ was effective in increasing CBS and $\mathrm{CTH}$ expressions and these stimulatory effects maximized with $10-100 \mathrm{nM} \mathrm{E}_{2} \beta$ at 48-72 h. $\mathrm{E}_{2} \beta$ also activated CBS and CTH promoters in UAEC, leading to CBS and CTH expression. Treatment with $\mathrm{E}_{2} \beta$ stimulated $\mathrm{H}_{2} \mathrm{~S}$ production, which was blocked by specific inhibitors of either CBS or CTH and their combination and the ER antagonist ICI 182780. Treatment with either specific agonist of $\operatorname{ER} \alpha$ or $\operatorname{ER} \beta$ stimulated both CBS and CTH mRNA and protein expressions and $\mathrm{H}_{2} \mathrm{~S}$ production to levels similar to that of $\mathrm{E}_{2} \beta$. Specific antagonist of either $\mathrm{ER} \alpha$ or $\mathrm{ER} \beta$ blocked $\mathrm{E}_{2} \beta$-stimulated CBS and CTH mRNA and protein expressions and $\mathrm{H}_{2} \mathrm{~S}$ production. Combinations of either $\mathrm{ER} \alpha$ or $\mathrm{ER} \beta$ agonists or their antagonists had no additive effects. Thus, $\mathrm{E}_{2} \beta$ stimulates $\mathrm{H}_{2} \mathrm{~S}$ production by upregulating $\mathrm{CBS}$ and $\mathrm{CTH}$ mRNA and protein expressions through specific $\mathrm{ER} \alpha$ or $\mathrm{ER} \beta$-dependent $C B S$ and $C T H$ transcription in UAEC in vitro.
\end{abstract}




\section{Summary Sentence}

Estradiol-17 $\beta$ stimulates uterine artery endothelial cell hydrogen sulfide biosynthesis.

Key words: estrogen, estrogen receptors, hydrogen sulfide, endothelium, uterine artery, vasodilation.

\section{Introduction}

Circulating estrogens are significantly elevated during the follicular phase of the ovarian cycle and pregnancy [1,2]. Estrogens are potent vasoactive hormones that dilate selected vasculature beds in organs throughout the body with the greatest response in reproductive tissues, especially the uterus $[3,4]$. The vasodilatory effect of estrogens is of major physiological significance during pregnancy because uterine vasodilation as measured by a rise in uterine blood flow (UBF) elevates more than 50 - to 80 -fold during pregnancy to facilitate the bidirectional mother-fetus exchanges of gases (i.e. $\mathrm{O}_{2}$ and $\mathrm{CO}_{2}$ ) and to provide the sole nutrient support to fetal development and survival [5]. Insufficient rise in UBF during pregnancy results in pregnancy disorders such as fetal growth restriction and preeclampsia [6], not only raising the risk of maternal and infant morbidity and mortality but also contributing to the susceptibility of both the mother and child to cardiovascular and other metabolic disorders later in life $[7,8]$.

Local uterine artery (UA) endothelium production of orchestrated vasodilators, including nitric oxide (NO) [9], endotheliumderived hyperpolarizing factor (EDHF) [10], and vascular endothelial growth factor (VEGFA) [11], etc., is crucial for mediating estrogen-induced and pregnancy-associated uterine vasodilation. Endothelial NO production via endothelial NO synthase (NOS3) activation and/or expression has been identified as a key player in uterine vasodilation as NOS3-derived NO is important for vascular remodeling, decreased vascular resistance, increased UBF, and pregnancy outcomes [12-15]. NOS3-derived NO seems to function as a focal mediator as it interacts with nearly all known vasodilators, including EDHF and VEGF [10,11]. However, blockade of local NO production only inhibits approximately $65 \%$ estradiol-17 $\beta$ (E2 $\beta)$ induced uterine vasodilation in nonpregnant ewes [9] and prolonged UA NOS inhibition only modestly reduces basal uteroplacental vasodilation in the last one third of ovine pregnancy [16], suggesting that mechanisms other than $\mathrm{NO}$ are present to maintain uterine hemodynamics.

Hydrogen sulfide $\left(\mathrm{H}_{2} \mathrm{~S}\right)$ is a gaseous signaling molecule that belongs to the gasotransmitter family after $\mathrm{NO}$ and carbon monoxide [17]. Endogenous $\mathrm{H}_{2} \mathrm{~S}$ in mammalian tissues is primarily synthesized via conversion of L-cysteine by two pyridoxal $5^{\prime}$-phosphatedependent enzymes cystathionine $\beta$-synthase (CBS) and cystathionine $\gamma$-lyase (CTH, also called CSE) [18-20]. In mammals, $\mathrm{H}_{2} \mathrm{~S}$ potently dilates various vasculatures via activating ATP-dependent potassium $\left(\mathrm{K}_{\mathrm{ATP}}\right)$ channel [21] and relaxes smooth muscle via activating large conductance calcium-activated potassium $\left(\mathrm{BK}_{\mathrm{Ca}}\right)$ channel [22]. We recently reported that a slow-releasing $\mathrm{H}_{2} \mathrm{~S}$ donor GYY4137 dose-dependently relaxes UAs from nonpregnant and pregnant rats, with significantly greater potency in the pregnant state and vascular bed specificity [23]. Others have shown $\mathrm{H}_{2} \mathrm{~S}$ to be a placental vasodilator $[24,25]$ and dysregulated $\mathrm{CTH} / \mathrm{H}_{2} \mathrm{~S}$ signaling in the placenta results in preeclampsia-like conditions [25]. Thus, $\mathrm{H}_{2} \mathrm{~S}$ plays an important role in uterine and placental hemodynamic regulation.

We have recently reported that both CBS and CTH are expressed in UA endothelium and smooth muscle in sheep [26] and human [23] $\mathrm{UAs}$ and both contribute to baseline $\mathrm{UA}_{2} \mathrm{~S}$ biosynthesis. However,
$\mathrm{UA}_{2} \mathrm{~S}$ biosynthesis and endothelium and smooth muscle CBS, but not $\mathrm{CTH}$, upregulation are significantly stimulated by exogenous $\mathrm{E}_{2} \beta$ in a sheep model of estrogen replacement therapy [26] and are associated elevated endogenous estrogens during the proliferative phase of the menstrual cycle and pregnancy in women [23]. These data show that CBS is the major enzymatic source of augmented UA $\mathrm{H}_{2} \mathrm{~S}$ biosynthesis in response to both exogenous and endogenous estrogen stimulation. However, the underlying mechanism by which estrogens regulate CBS expression to stimulate $\mathrm{H}_{2} \mathrm{~S}$ biosynthesis is unknown in UA vascular cells.

Estrogens elicit diverse biological functions in target cells/tissues that possess specific ERs (i.e. $\mathrm{ER} \alpha$ and $\mathrm{ER} \beta$ ) [27, 28], including vascular endothelial cells (ECs) such as uterine artery ECs (UAEC) [29]. By binding to specific transcription factor ERs, estrogens initiate the transcription of target genes that possess estrogen-responsive elements in their promoters in the nucleus [30]. Estrogen-induced uterine vasodilation is at least partially mediated by specific estrogen receptors since both exogenous and endogenous estrogen-induced rises in UBF can be inhibited by ICI 182780 (ICI) [31]. We hypothesize herein that estrogens stimulate $\mathrm{H}_{2} \mathrm{~S}$ biosynthesis by specific $\mathrm{ER} \alpha$ and/or ER $\beta$-dependent upregulation of CBS transcription. The objectives of this study were to determine in cultured UAEC whether (1) $\mathrm{E}_{2} \beta$ stimulates $\mathrm{H}_{2} \mathrm{~S}$ production with enhanced mRNA and protein expression of CBS and/or CTH; (2) $\mathrm{E}_{2} \beta$ stimulation of CBS and/or CTH expression is mediated by ER-dependent transcription; and (3) ER $\alpha$ and $\mathrm{ER} \beta$ plays different roles in $\mathrm{E}_{2} \beta$-stimulated $\mathrm{H}_{2} \mathrm{~S}$ biosynthesis.

\section{Materials and methods}

\section{Chemicals and antibodies}

$\mathrm{E}_{2} \beta$, hydroxyethylpiperazine- $\mathrm{N}^{\prime}$-2-ethanesulfonic acid (HEPES), fatty acid free bovine serum albumin (BSA), O-(carboxymethyl) hydroxylamine hemihydrochloride $(\mathrm{CHH})$, sodium dodecyl sulfate (SDS), and all other chemicals unless specified were from Sigma (St. Louis, MO). ICI 182780 (ICI), 4,4,4-(4-propyl-[1H]-pyrazole1,3,5-triyl)trisphenol (PPT), diarylpropionitrile (DPN), 1,3-Bis(4hydroxyphenyl)-4-methyl-5-[4-(2-piperidinylethoxy)phenol]-1Hpyrazole dihydrochloride (MPP), 4-[2-Phenyl-5,7-bis (trifluoromethyl)pyrazolo[1,5-a]pyrimidin-3yl]phenol (PHTPP) were from Tocris (Ellisville, $\mathrm{MO}$ ). $\beta$-cyano-L-alanine (BCA) was from Cayman Chemical (Ann Arbor, MI). Anti-ACTH monoclonal antibody was from Ambion (Austin, TX). Monoclonal antibodies of CBS and CTH were from Santa Cruz Biotechnology, Inc (Santa Cruz, CA). Anti-biotin antibody was from Cell Signaling Technology (Beverly, MA). Cell culture media MCDB131 and M199, prolong gold antifade reagent with 4',6-diamidino-2-phenylindole (DAPI), and Alexa ${ }^{488}$ goat anti-mouse IgG were from Invitrogen (Carlsbad, CA).

\section{Cell culture and treatments}

Primary UAEC were isolated by collagenase digestion from late pregnant ewes (120-130 days of gestation, normal term $\approx 145$ days) as previously described $[13,32]$. The Animal Care and Use Committee from the University of California approved the animal use protocol. 
Frozen UAEC aliquots (passage 2) were thawed and seeded in MCDB131 containing 10\% fetal bovine serum (Lonza, Walkersville, $\mathrm{MD})$ and $1 \%$ antibiotics for experimental use at passages $4-5$. Briefly, cells at approximately $70 \%$ confluence were cultured in serum/phenol red-free M-199 medium containing $0.1 \%$ fatty acid-free BSA, $0.5 \%$ charcoal stripped FBS, $1 \%$ penicillin/ streptomycin, and $25 \mathrm{mM}$ HEPES overnight for approximately $16 \mathrm{~h}$. Following equilibration in fresh serum-free M-199, cells were treated with $\mathrm{E}_{2} \beta$, ER agonists, or $\mathrm{E}_{2} \beta$ with or without $\mathrm{ER}$ antagonists as previously described [32]. Ethanol was the vehicle used to dissolve $\mathrm{E}_{2} \beta$ and ER agonists and antagonists. Final ethanol concentrations used were less than $0.5 \%$ and did not alter cellular responses surveyed in this study.

\section{Methylene blue assay}

UAEC $\left(1 \times 10^{6} /\right.$ treatment in duplicate $)$ were homogenized in $50 \mathrm{mM}$ ice-cold potassium phosphate buffer $\mathrm{pH}$ 8.0. Using the methylene blue assay, $\mathrm{H}_{2} \mathrm{~S}$ production was determined as previously described $[23,26]$. The $\mathrm{H}_{2} \mathrm{~S}$ concentration was calculated based on a calibration curve generated from $\mathrm{NaHS}$ solutions. $\mathrm{CHH}$ or $\mathrm{BCA}$ at a final concentration of $2 \mathrm{mM}$ was added to the reaction mixtures prior to initiating the assay for determining specific CBS and CTH activities, respectively.

\section{RNA extraction, polymerase chain reaction, and quantitative real-time RT-PCR}

RNA extraction, polymerase chain reaction (PCR), and quantitative real-time RT-PCR was performed as previously described [23, 26]. Comparative CT method ( $\Delta \Delta \mathrm{CT}$ method) was used to calculate mRNA expression with L19 as the internal reference control.

\section{SDS-PAGE and immunoblotting}

SDS-PAGE and immunoblotting with specific antibodies listed in supplemental table S1 were performed as previously described [23, 26].

\section{Immunofluorescence microscopy}

UAEC were grown on glass coverslips to reach approximately $80 \%$ confluence and treated as described above. Following treatments, cells were washed in PBS and fixed in $4 \%$ paraformaldehyde for $20 \mathrm{~min}$ at room temperature. Cells were permeablized by incubating in $0.2 \%$ Triton-X in PBS for $15 \mathrm{~min}$ at room temperature. Autofluorescence was quenched by washing with $300 \mathrm{mM}$ glycine in PBS, and nonspecific binding was blocked by incubation with PBS containing $1 \%$ BSA, $0.125 \%$ saponin, and $1 \%$ gelatin. Cells were incubated with $1 \mu \mathrm{g} / \mathrm{mL}$ of anti-CBS or anti-CTH. Following incubation with Alexa ${ }^{488}$-labeled secondary antibody $(1: 1000)$, coverslips were mounted onto slides with Prolong Gold antifade reagent (Invitrogen) containing DAPI. Slides were examined under a Leica fluorescence microscope (Leica Corporation, Deerfield, IL). Digital images were acquired using a CCD camera and SimplePCI image analysis software (Hamamatsu Corporation, Sewickley, PA) and used for determining relative $\mathrm{CBS}$ and $\mathrm{CTH}$ proteins by quantifying mean green fluorescence intensity (15 cells/image and 5 images/animal) using SimplePCI. Normalized CBS and CTH protein levels were presented as fold change in the average fluorescence intensity of vehicle control treated cells.

\section{Cell transfection and luciferase assay}

RenSP luciferase-reporter constructs containing the promoters of human CBS (S711027), CTH (S712215), $\beta$-actin (S717678), and all transfection and luciferase reagents were purchased from Switchgear Genomics (Carlsbad, CA). The RenSP luciferase plasmid DNA and cypridina luciferase TK control construct were co-transfected into UAEC by using FuGENE HD transfection reagents $(1: 3, \mu 1 / n g)$ for $24 \mathrm{~h}$ at $37^{\circ} \mathrm{C}$. UAEC transfected with an empty vector and $\beta$-actin promoter vector were served as negative and positive transfection controls, respectively. After transfection, cells were allowed to recover for 18-20 h in DMEM containing 10\% FBS. Cells were serumstarved overnight and treated with vehicle or $\mathrm{E}_{2} \beta(10 \mathrm{nM})$ for $24 \mathrm{~h}$ with or without ICI 182780. The RenSP luciferase activity in both cells and supernatant was measured and normalized to cypridina luciferase activity as previously described [33].

\section{Statistical analysis}

Each experiment was repeated at least three times with cells derived from different pregnant ewes. Data are presented as means \pm SEM and analyzed by one-way or two-way analysis of variance (ANOVA), followed by the Bonferroni test for multiple comparisons using SigmaPlot (Systat Software Inc.). Student paired $t$-test was used for comparison of data between two groups. Significance was defined as $P<0.05$, unless higher statistical power is indicated in the figure legends.

\section{Results}

\section{$\mathrm{E}_{2} \beta$ stimulates $\mathrm{H}_{2} \mathrm{~S}$ production: role of $\mathrm{CBS}, \mathrm{CTH}$, and $\mathrm{ER}$}

Compared to vehicle-treated controls, treatment with $\mathrm{E}_{2} \beta(10 \mathrm{nM})$ for $48 \mathrm{~h}$ stimulated a $2.43 \pm 0.21$-fold $(P<0.01)$ increase in $\mathrm{H}_{2} \mathrm{~S}$ production in UAEC in vitro. The stimulation was blocked by pretreatment with $1 \mu \mathrm{M} \mathrm{ICI}$; incubation with ICI alone had no effect (Figure $1 \mathrm{~A}$ ). $\mathrm{E}_{2} \beta$-stimulated $\mathrm{H}_{2} \mathrm{~S}$ production was significantly inhibited by the specific CBS inhibitor $\mathrm{CHH}$ or CSE inhibitor BCA alone; the combination of $\mathrm{CHH}$ and BCA completely blocked $\mathrm{E}_{2} \beta$ stimulated $\mathrm{H}_{2} \mathrm{~S}$ production (Figure $1 \mathrm{~B}$ ).

\section{$\mathrm{E}_{2} \beta$ stimulates CBS and CTH mRNA/protein expressions in a time- and concentration-dependent manner}

$\mathrm{E}_{2} \beta$ significantly stimulated CBS and CTH mRNAs in a timedependent manner in UAEC in vitro. Following treatment with $10 \mathrm{nM} \mathrm{E}_{2} \beta$, both CBS and CTH mRNA levels began to increase significantly at $24 \mathrm{~h}$, maximized at $48 \mathrm{~h}$ (CBS: $2.61 \pm 0.27$-fold vs control; $P<0.01$; CTH: $3.24 \pm 0.41$ fold vs control, $P<0.01$ ), and plateaued at $72 \mathrm{~h}$ (Figure $2 \mathrm{~A}$ ). $\mathrm{E}_{2} \beta$ also significantly stimulated CBS and $\mathrm{CTH}$ proteins in a time-dependent manner. Following treatment with $10 \mathrm{nM} \mathrm{E}_{2} \beta$, both CBS and CTH protein levels began to significantly increase at $24 \mathrm{~h}$ and the stimulation continued up to 3 days (Figure 2B).

$\mathrm{E}_{2} \beta$ also significantly stimulated CBS and CTH mRNAs in a concentration-dependent manner in UAEC in vitro. Treatment with $0.1 \mathrm{nM} \mathrm{E}_{2} \beta$ for $48 \mathrm{~h}$ effectively stimulated both CBS and CTH mRNA expressions. Within the $\mathrm{E}_{2} \beta$ concentrations tested, CBS mRNA continued to increase and maximized at $1 \mu \mathrm{M}(3.02 \pm 0.32-$ fold vs control, $P<0.01)$. CTH mRNA maximized by treatment with $10 \mathrm{nM} \mathrm{E}_{2} \beta(3.25 \pm 0.41$-fold vs control, $P<0.01)$ and plateaued 

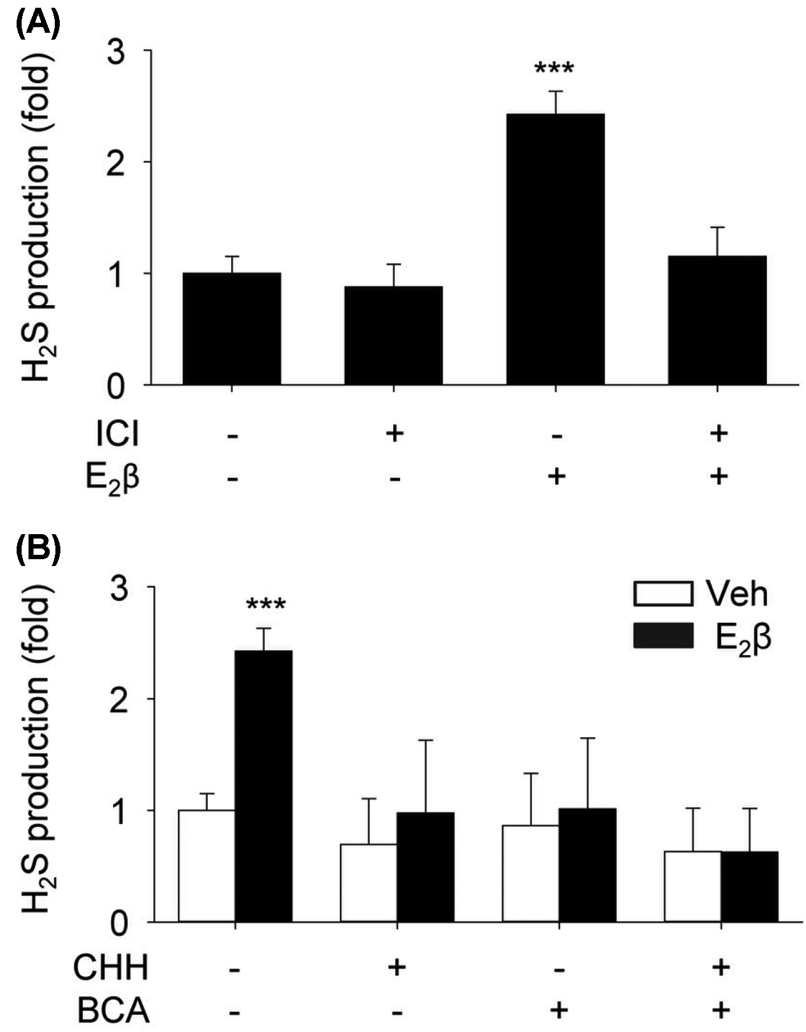

Figure 1. Effects of $\mathrm{E}_{2} \beta$ on $\mathrm{H}_{2} \mathrm{~S}$ production-role of $\mathrm{CBS}, \mathrm{CTH}$, and ER. (A) Primary uterine artery endothelial cells (UAEC) were treated with vehicle or estradiol-17 $\beta\left(\mathrm{E}_{2} \beta, 10 \mathrm{nM}\right)$ with or without the estrogen receptor (ER) antagonist ICl $182780(\mathrm{ICl}, 1 \mu \mathrm{M})$ for $48 \mathrm{~h}$. Protein extracts $\left(1 \times 10^{6}\right.$ cells) were used to determine hydrogen sulfide $\left(\mathrm{H}_{2} \mathrm{~S}\right)$ production. (B) UAEC were treated with vehicle or $10 \mathrm{nM} \mathrm{E} \beta$ for $48 \mathrm{~h}$, and protein extracts were used to determine $\mathrm{H}_{2} \mathrm{~S}$ production in the presence or absence of an inhibitor of cystathionine $\beta$-synthase (CBS, cystathionine $\gamma$-lyase $(\mathrm{CTH})$, or $\mathrm{CHH}$ and $\mathrm{BCA}$, respectively. Data (means \pm SEM) were collected from different cell preparations cells prepared from three to five ewes. ${ }^{* * *} P<0.001$ vs control.

with $1 \mu \mathrm{M} \mathrm{E}_{2} \beta$ (Figure 2C). Treatment with $0.1 \mathrm{nM} \mathrm{E}_{2} \beta$ for $48 \mathrm{~h}$ effectively stimulated both CBS and CTH proteins. The responses increased with increasing concentrations of $\mathrm{E}_{2} \beta$, and maximized with $100 \mathrm{nM} \mathrm{E}_{2} \beta$ (CBS: $3.04 \pm 0.16$-fold vs control, $P<0.01$; CTH: $3.17 \pm 0.63$ fold vs control, $P<0.01$ ) (Figure $2 \mathrm{D}$ ).

\section{$\mathrm{E}_{2} \beta$ stimulation of CBS and CTH expressions is mediated by specific ERs}

In the presence of the specific ER antagonist ICI $(1 \mu \mathrm{M}), \mathrm{E}_{2} \beta$ stimulated CBS and CTH mRNAs (Figure 3A) were completely abrogated. Treatment with $10 \mathrm{nM} \mathrm{E} 2 \beta$ for $48 \mathrm{~h}$ also significantly stimulated CBS $(2.46 \pm 0.17$-fold vs control, $P<0.01)$ and CTH $(2.39 \pm 0.10$-fold vs control, $P<0.01)$ protein expressions, which were completely blocked by ICI (Figure $3 \mathrm{~B}$ ). Immunofluorescence analysis with specific anti-CBS and anti-CTH antibodies showed relative low baseline CBS and high CTH proteins in UAEC and confirmed ICI blockade of $\mathrm{E}_{2} \beta$ stimulation of CBS and CTH protein expressions (Figure 3C). Treatments with vehicle or ICI alone did not alter CBS and CTH mRNA and protein expressions.

\section{Either $\mathrm{ER} \alpha$ or $\mathrm{ER} \beta$ is sufficient to mediate $\mathrm{E}_{2} \beta$} stimulation of CBS and CTH expressions

UAEC expresses both ER $\alpha$ and $\mathrm{ER} \beta$ [29] and they may play common or even opposite roles in mediating estrogen regulation of gene expression in a cell [34]; we determined the specific roles of ER $\alpha$ and $\mathrm{ER} \beta$ in estrogen stimulation of CBS and CTH expressions by using ER isoform-specific agonists or antagonists. Compared to vehicletreated controls, treatment with the ER $\alpha$ agonist PPT alone induced $2.55 \pm 0.26$-fold $(P<0.01)$ and $2.98 \pm 0.91$-fold $(P<0.01)$ increases in CBS and CTH mRNAs, respectively. Treatment with the $\mathrm{ER} \beta$ agonist DPN alone induced $2.45 \pm 0.15$-fold $(P<0.01)$ and $2.39 \pm 0.41$-fold $(P<0.01)$ increases in CBS and CTH mRNAs, respectively (Figure 4A). These increases were comparable to that of $\mathrm{E}_{2} \beta$-stimulated fold increases in $\mathrm{CBS}(2.61 \pm 0.27$ vs vehicle, $P<0.01)$ and CTH $(3.25 \pm 0.41$ vs vehicle, $P<0.01)$ mRNAs, respectively. PPT alone induced $2.02 \pm 0.12$-fold $(P<0.01)$ and $2.70 \pm 0.39$-fold $(P<0.01)$ increases in CBS and CTH proteins, respectively; DPN alone induced $2.69 \pm 0.12$-fold $(P<0.01)$ and $2.80 \pm 0.17$-fold $(P<0.01)$ increases in CBS and CTH proteins, respectively (Figure $4 \mathrm{~B}$ ). These changes were also comparable to that of $\mathrm{E}_{2} \beta$-stimulated fold increases in CBS $(2.46 \pm 0.17$ vs vehicle, $P<0.01)$ and CTH $(2.39 \pm 0.10$ vs vehicle, $P<0.01)$ proteins, respectively. The combination of PPT and DPN had no additive effects on either CBS or CTH mRNA and protein expressions (Figure 4). Treatment with either ER $\alpha$ antagonist MPP or ER $\beta$ antagonist PHTPP alone or their combination was sufficient to completely attenuate $\mathrm{E}_{2} \beta$-stimulated CBS and CTH mRNA (Figure 4C) and protein (Figure 4D) expressions.

\section{$\mathrm{E}_{2} \beta$ stimulates ER-dependent activation of $C B S$ and CTH promoters}

Compared to vehicle-treated controls, treatment with $10 \mathrm{nM} \mathrm{E}_{2} \beta$ for $24 \mathrm{~h}$ significantly stimulated the promoter activities of $C B S$ (3.71 \pm 0.65 -fold, $P<0.001)$ and CTH $(3.77 \pm 0.31$-fold, $P<0.001)$ in UAEC. Co-treatment with ICI completely attenuated $\mathrm{E}_{2} \beta$-stimulated activation of $\mathrm{CBS}$ and $\mathrm{CTH}$ promoters (Figure 5).

\section{Discussion}

Consistent with our most recent in vivo findings that $\mathrm{UA}_{2} \mathrm{~S}$ production and endothelium and smooth muscle CBS but not CSE expressions are significantly greater in the proliferative phase and pregnancy, positively linked to elevated endogenous estrogens in women [23] and that exogenous estrogens significantly stimulate $\mathrm{UA} \mathrm{H}_{2} \mathrm{~S}$ biosynthesis via selective upregulation of endothelium and smooth muscle CBS, but not CTH, mRNA, and protein expressions in OVX ewes [26], we now report that $\mathrm{E}_{2} \beta$ stimulates UAEC $\mathrm{H}_{2} \mathrm{~S}$ production in association with upregulation of not only CBS but also CSE expression in vitro. The stimulatory effect of $\mathrm{E}_{2} \beta$ on CTH mRNA and protein expression in UAEC in vitro is unexpected; however, the increased CBS and CTH protein expressions contribute to the increased $\mathrm{H}_{2} \mathrm{~S}$ production upon $\mathrm{E}_{2} \beta$ stimulation in UAEC in vitro because UAEC $\mathrm{H}_{2} \mathrm{~S}$ production can be significantly inhibited by the specific inhibitor of either CBS $(\mathrm{CHH})$ or $\mathrm{CTH}(\mathrm{BCA})$ alone and completely by their combination.

Our current data shown that $\mathrm{E}_{2} \beta$ stimulates CBS mRNA and protein expressions in a time- and concentration-dependent manner, with as little as $0.1 \mathrm{nM} \mathrm{E}_{2} \beta$ being effective to stimulate both CBS mRNA and protein expressions in UAEC. This low-dose $\mathrm{E}_{2} \beta$ is physiologically relevant because $0.1-10 \mathrm{nM} \mathrm{E}_{2} \beta$ is in the range 

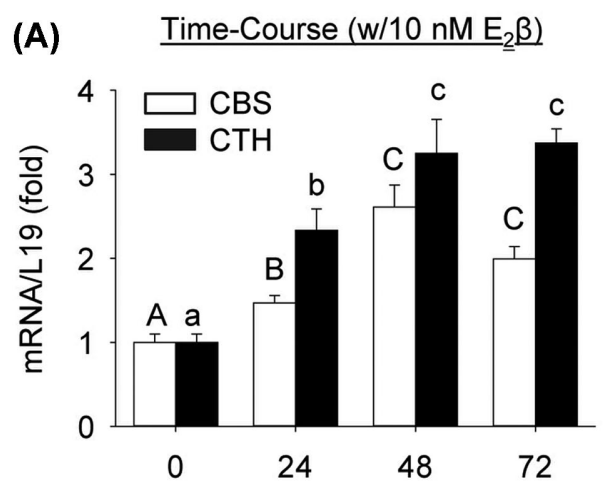

(C)
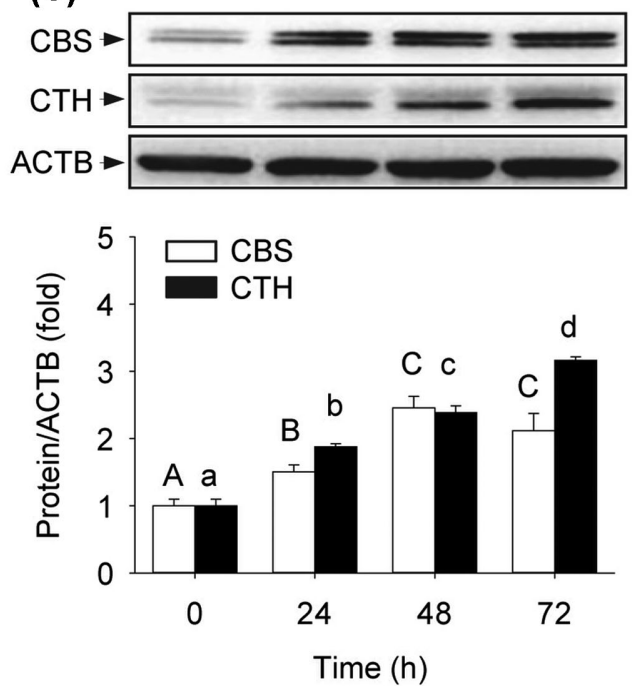

(B) Dose-response (@48 h)

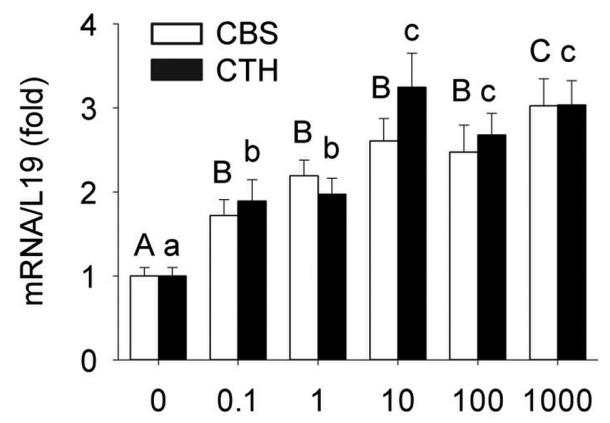

(D)
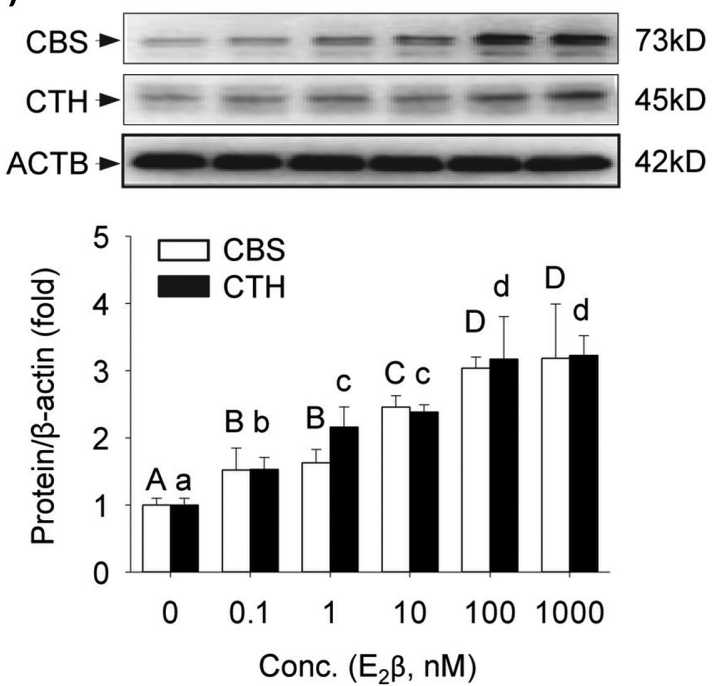

Figure 2. Time course and concentration response of $\mathrm{E}_{2} \beta$ on mRNA and protein expressions of CBS and CTH. Primary uterine artery endothelial cells (UAEC) were treated with $10 \mathrm{nM}$ estradiol-17 $\beta\left(\mathrm{E}_{2} \beta\right)$ for up to 3 days to assess cystathionine $\beta$-synthase (CBS) and cystathionine $\gamma$-lyase (CTH) mRNA (A) and protein (B), or with increasing concentrations of $E_{2} \beta(0-1 \mu \mathrm{M})$ for $48 \mathrm{~h}$ to assess CBS and CTH mRNA (C) and protein (D). Data (means \pm SEM) were collected from different cell preparations cells prepared from three to five ewes. Bars with different letters differ significantly $(P<0.05)$; capital and lower case letters pertain to $\mathrm{CBS}$ and $\mathrm{CTH}$, respectively.

of circulating estrogen levels in nonpregnant and pregnant states [1, $35,36]$. Together with our recent in vivo findings [23, 26], these observations further strengthened $C B S$ as an estrogen-responsive gene in ECs. $\mathrm{E}_{2} \beta$ stimulates both mRNA and protein expressions of CBS in UAEC in vitro, suggesting that the stimulation occurs mainly at the level of transcription. Indeed, $\mathrm{E}_{2} \beta$ activates the CBS promoter in UAEC in vitro. ICI completely attenuates $\mathrm{E}_{2} \beta$ stimulation of CBS mRNA and protein expressions as well as its promoter activation, indicating the involvement of specific ERs.

We have previously shown that UAEC are direct targets of estrogens as both $\mathrm{ER} \alpha$ and $\mathrm{ER} \beta$ are expressed in UAEC [29, 37]. In target cells expressing $\mathrm{ER} \alpha$ and $\mathrm{ER} \beta$, ligated receptors function as transcription factors to regulate gene expression via interaction with estrogen response elements (ERE) in the promoter of target genes [28]. In this mode, estrogens also regulate the expression of genes without classical EREs via crosstalk between ligated ERs with other ERE-interacting transcription factors such as AP-1 or Sp1 [27, 38]. The genomic effects of estrogens regulate the expression of various genes that are key enzymes such as NOS3 [39] and prostaglandin synthase [40] for synthesizing NO and prostacyclin, respectively. In addition, $\mathrm{ER} \alpha$ and $\mathrm{ER} \beta$ may play different and even opposite roles in regulating cellular responses to estrogens [34]. We show herein that either PPT or DPN stimulates CBS mRNA and protein expressions to levels comparable to that of $\mathrm{E}_{2} \beta$-stimulated. Co-treatment with either MPP or PHTPP attenuates $\mathrm{E}_{2} \beta$-stimulated CBS mRNA and protein expressions and neither the combination of the agonists nor the antagonists have additive effects. Thus, activation of either ER $\alpha$ or $\mathrm{ER} \beta$ is sufficient to mediate $\mathrm{E}_{2} \beta$ stimulation of $\mathrm{CBS}$ expression in UAEC in vitro.

$\mathrm{E}_{2} \beta$ also stimulates $\mathrm{CTH}$ mRNA and protein expressions in UAEC in vitro, similar to its effects on CBS expression. Also similar is that $\mathrm{E}_{2} \beta$ stimulation of CTH mRNA and protein expressions is mediated by ER-dependent CTH transcription, which can be activated by either $\mathrm{ER} \alpha$ or $\mathrm{ER} \beta$ because $\mathrm{E}_{2} \beta$ stimulates $\mathrm{CTH}$ mRNA and protein expressions as well as $\mathrm{CTH}$ promoter activation and all responses can be blocked by ICI. Thus, these data demonstrate that $\mathrm{CTH}$ is also an estrogen-responsive gene in UAEC in vitro. Nonetheless, estrogen stimulation of CTH expression is unexpected because it contradicts not only to our in vivo studies showing that exogenous or endogenous $\mathrm{E}_{2} \beta$ does not alter CTH mRNA and protein in UA endothelium in women [23] and sheep [26], but also to other studies showing that $\mathrm{E}_{2} \beta$ does not stimulate CTH expression in mouse mesenteric smooth muscle cells in vitro [41]. The mechanism underlying the discrepancy between the effect of $\mathrm{E}_{2} \beta$ on $\mathrm{CTH}$ expression 

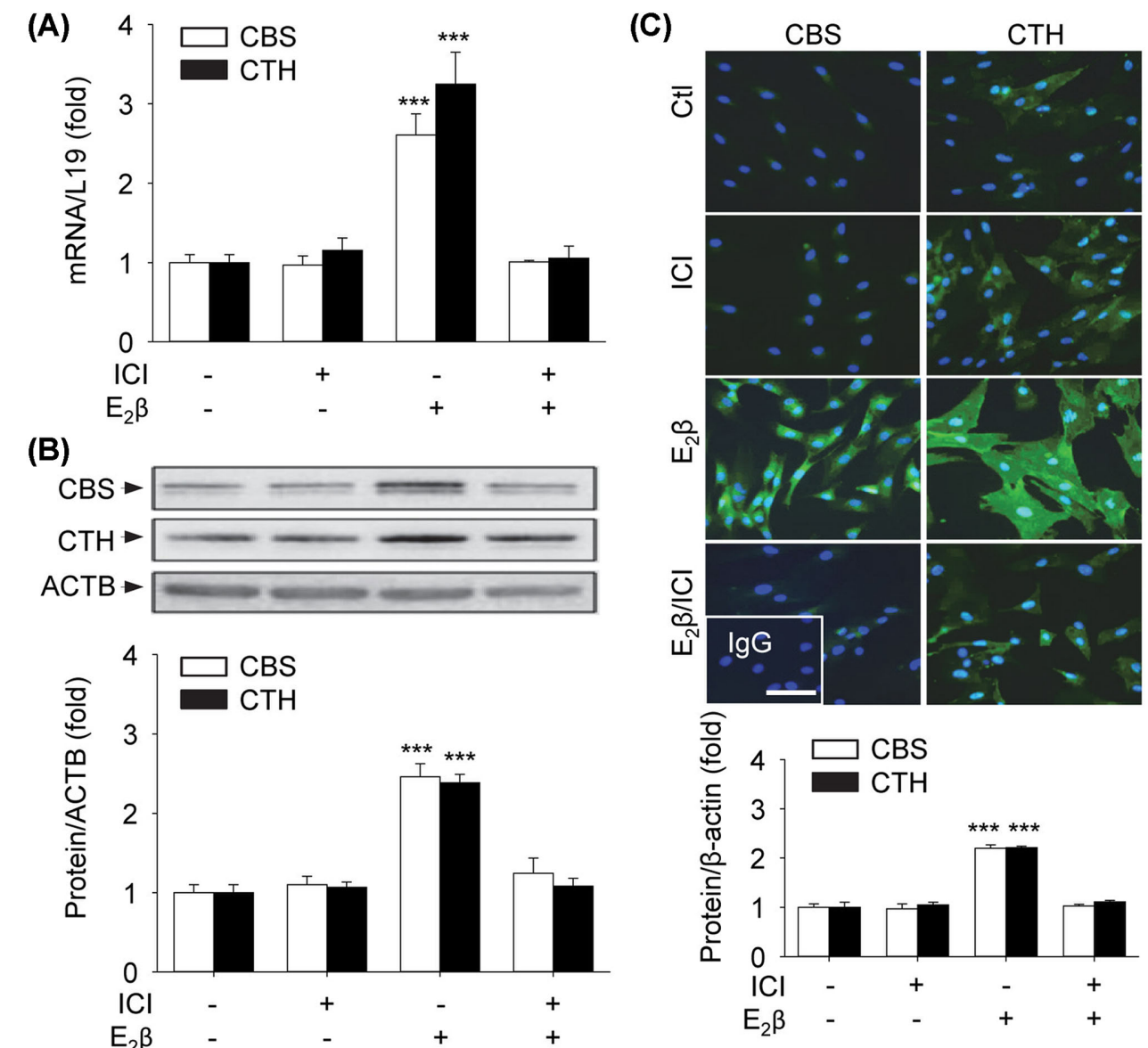

Figure 3. ER-dependency of $\mathrm{E}_{2} \beta$ effects on mRNA and protein expressions of CBS and CTH. Primary uterine artery endothelial cells (UAECs) were treated with vehicle, $10 \mathrm{nM}$ estradiol-17 $\beta\left(\mathrm{E}_{2} \beta\right), 1 \mu \mathrm{M} \mathrm{ICl} 182780(\mathrm{ICI})$, or both for $48 \mathrm{~h}$. Cystathionine $\beta$-synthase (CBS) and cystathionine $\gamma$-lyase (CTH) mRNA (A) and protein (B) were determined. (C) Immunofluorescence labeling of CBS and CTH proteins. Nuclei were stained with DAPI (blue). Protein expression was determined by relative green fluorescence intensity as fold change of control. Data (means \pm SEM) were collected from different cell preparations from three to five ewes. **** $P<0.001$ vs. Control. Scale bar $=50 \mu \mathrm{m}$.

in UAEC in vitro and in vivo is currently unknown. However, it is not uncommon that in vitro experiments do not always agree with in vivo findings. Nonetheless, this discrepancy is at least, in part, due to loss of cell-cell interactions and the microenvironment that ECs reside in in vivo. Regardless, caution should be exercised when interpreting in vitro findings as they pertain to in vivo conditions because in vitro and in vivo studies can sometimes produce different outcomes.

Although our current study shows that $\mathrm{E}_{2} \beta$ activates CBS and CTH transcription that is linked to ER activation in UAEC, it does not provide direct evidence as to how ER interacts with the regulatory cis-elements in $C B S$ and $C T H$ promoters. The human $C B S$ promoter spans over $>4 \mathrm{~K}$ bp [42] and the $C T H$ promoter is approximately $1000 \mathrm{bp}$ in length [43]. Both contain multiple putative ciselements for binding various transcription factors, including ERE, Sp1, AP-1, and AP-3 [43, 44]. AP-1 and Sp1 have been implicated in stimulating CTH expression in vascular smooth muscle cells [43] as well as CTH [45] and CBS [42] expression in hepatocellular carcinoma cells. Since $\mathrm{E}_{2} \beta$ stimulation of CBS and CTH expression in UAEC and trans-activation of their promoters by $\mathrm{E}_{2} \beta$ is blocked by ICI, it is reasonable to infer that estrogen stimulation of CBS and $\mathrm{CTH}$ expression is mediated mainly by $\mathrm{ER}(\mathrm{ER} \alpha$ and/or $\mathrm{ER} \beta$ ) interaction with ERE. However, others transcription factors, such as Sp1 and AP1, cannot be excluded because $\mathrm{E}_{2} \beta$ can stimulate gene expression through interactions of ER with other transcription factors [38].

Of note, in addition to $\mathrm{ER} \alpha$ and $\mathrm{ER} \beta$, estrogens also signal via $\mathrm{G}$ protein-coupled estrogen receptor 1 (GPER) located on the plasma membrane $[46,47]$. In this "extranuclear" nongenomic mode of estrogen signaling, binding to membrane $\mathrm{ER} \alpha, \mathrm{ER} \beta$, or GPER activates multiple protein kinase cascades within seconds to minutes to activate downstream target proteins to elicit biological functions or nuclear transcription factors to regulate latent gene expression [47]. ER $\alpha$ and $\operatorname{ER} \beta$ [29] and GPER [48] are expressed in UA. The nongenomic action of estrogens is also of critical importance to the vascular effects of estrogens. For instance, activation of extracellular signal-activated protein kinases [13] and protein kinase B/Akt1 [49] via membrane ER-mediated mechanisms mediates rapid activation of NOS3 to produce NO by $\mathrm{E}_{2} \beta$ in ECs, which contributes greatly to the endothelium-dependent mechanisms for the vascular effects of estrogens [50], including estrogen-induced uterine vasodilation [48]. To this end, whether estrogens activate the $\mathrm{H}_{2} \mathrm{~S}$ system via nongenomic pathway awaits to be determined.

In summary, our present study demonstrates that $\mathrm{E}_{2} \beta$ stimulates $\mathrm{H}_{2} \mathrm{~S}$ production by upregulating CBS and CTH mRNA and protein expressions through specific ER-dependent $C B S$ and $C T H$ 
(A)

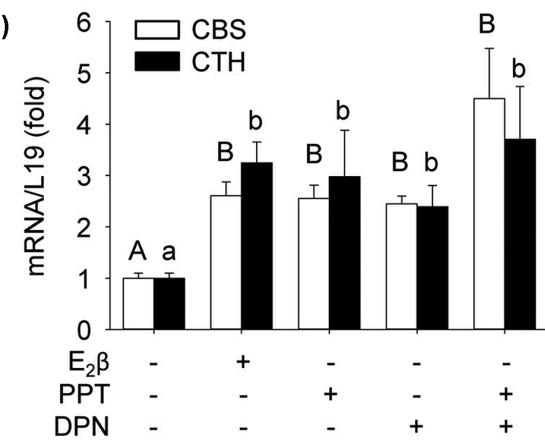

(B)
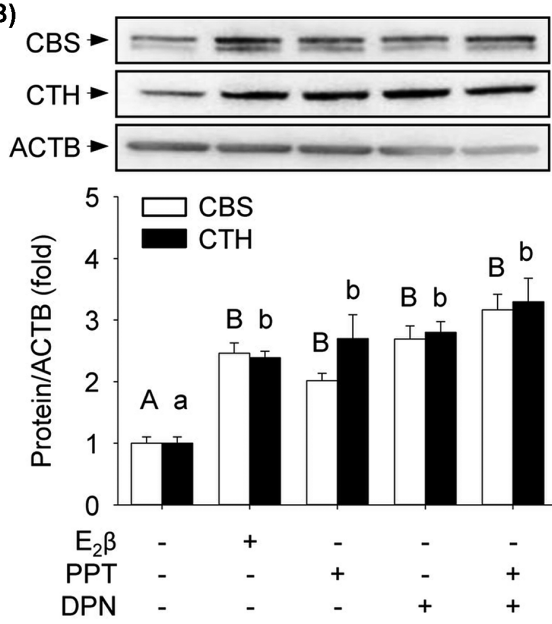

(C)

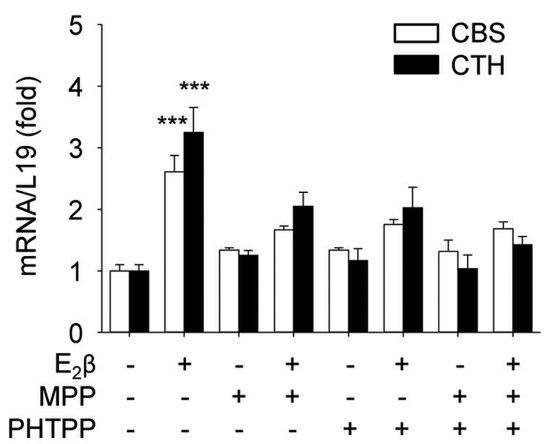

(D)
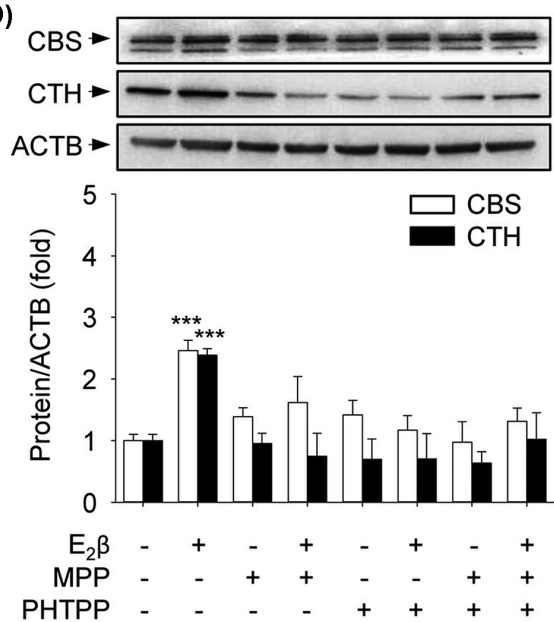

Figure 4. Specific role of $\mathrm{ER} \alpha$ or $\mathrm{ER} \beta$ in mediating $\mathrm{E}_{2} \beta$ stimulation of mRNA and protein expressions of CBS and CTH. (A, B) ER $\alpha$ or ER $\beta$ activation: primary uterine artery endothelial cells (UAECs) were treated with vehicle, $10 \mathrm{nM}$ of estradiol-17 $\beta$ (E $2 \beta$ ), PPT (ER $\alpha$ agonist), DPN (ER $\beta$ agonist), or PPT + DPN for $48 \mathrm{~h}$. (C, D) ER $\alpha$ or $\mathrm{ER} \beta$ inhibition: primary uterine artery endothelial cells (UAECs) were treated with vehicle or estradiol-17 $\beta$ ( $\left.\mathrm{E}_{2} \beta\right)(10 \mathrm{nM})$ with or without $1 \mu \mathrm{M}$ MPP (ER $\alpha$ antagonist), PHTPP (ER $\beta$ antagonist), or MPP + PHTPP. Cystathionine $\beta$-synthase (CBS) and cystathionine $\gamma$-lyase (CTH) mRNA (A, C) and protein (B, $D$ ) were determined. Data (means $\pm S E M$ ) were collected from different cell preparations from three to five ewes. Bars with different letters differ significantly; capital and lower case letters pertain to $\mathrm{CBS}$ and $\mathrm{CTH}$, respectively. ${ }^{* * *} P<0.001$ vs Control.

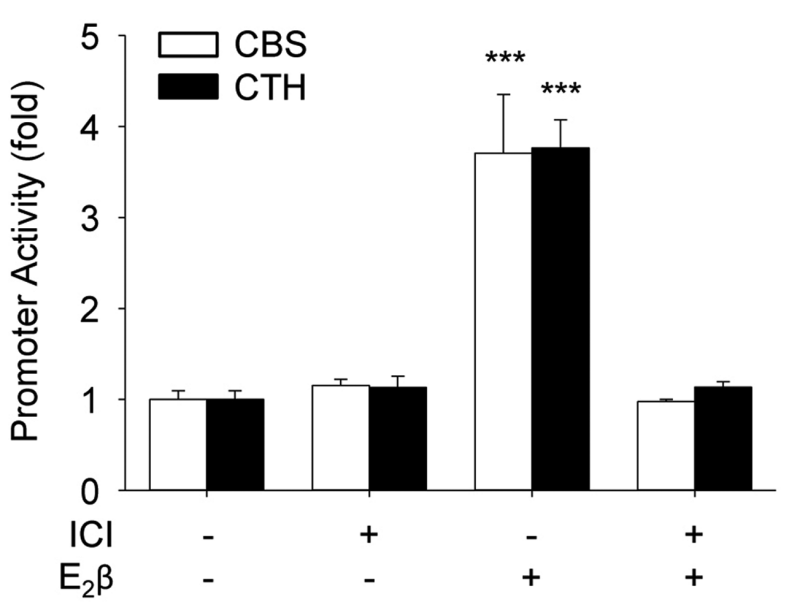

Figure 5. ER-dependency of $\mathrm{E}_{2} \beta$ activation of $C B S$ and $C T H$ promoters. Human cystathionine $\beta$-synthase (CBS) and cystathionine $\gamma$-lyase $(C T H)$ promoter luciferase-reporter constructs were transfected into primary uterine artery endothelial cells (UAECs). Twenty-four hours later, the cells were treated with vehicle or estradiol-17 $\beta\left(\mathrm{E}_{2} \beta, 10 \mathrm{nM}\right)$ with or without estrogen receptor (ER) antagonist ICI $182780(\mathrm{ICl}, 1 \mu \mathrm{M})$ for $24 \mathrm{~h}$. Luciferase activity was determined as an index for promoter action. Data (means \pm SEM) were collected from cells prepared from three to five ewes. ${ }^{* * *} P<0.001$ vs Control. transcription in UAEC in vitro. Estrogen stimulation of $\mathrm{H}_{2} \mathrm{~S}$ biosynthesis in UAEC in vivo $[23,26]$ and in vitro (current study) obviously raises a question as to what role $\mathrm{H}_{2} \mathrm{~S}$ plays in the UA. We believe that our findings underline a physiological role of $\mathrm{H}_{2} \mathrm{~S}$ in mediating estrogen-induced and pregnancy-associated rises in UBF due to the potent vasodilatory properties of $\mathrm{H}_{2} \mathrm{~S}$ [21]. This idea is supported by observations that exogenous $\mathrm{H}_{2} \mathrm{~S}$ donor dilates rat UA more effectively in P vs NP states [23], although a role of endogenous $\mathrm{H}_{2} \mathrm{~S}$ in mediating uterine vasodilation is waiting to be determined.

\section{Supplementary data}

Supplementary data are available at BIOLRE online.

Supplementary Table S1. Antibody Table.

\section{Sources of funding}

TJL was an American Heart Association (AHA) Pre-doctoral Fellow ( AHA14PRE18570033). This study was supported in part by National Institutes of Health (NIH) grants RO1HL70562 and R21HL98746 to DBC and PO1HD38843, RO1HL87144, and RO1HL117341 to RRM. The content is solely the responsibility of 
the authors and does not necessarily the official views of NIH and AHA.

Conflict of Interest/Disclosure Statement: The authors have no financial interests to disclose.

\section{References}

1. O'Leary P, Boyne P, Flett P, Beilby J, James I. Longitudinal assessment of changes in reproductive hormones during normal pregnancy. Clin Chem 1991; 37:667-672.

2. Albrecht ED, Pepe GJ. Placental steroid hormone biosynthesis in primate pregnancy. Endocr Rev 1990; 11:124-150.

3. Rosenfeld CR. Responses of reproductive and nonreproductive tissues to 17 beta-estradiol during ovine puerperium. Am J Physiol 1980; 239:E333E339.

4. Magness RR, Rosenfeld CR. Local and systemic estradiol-17 beta: effects on uterine and systemic vasodilation. Am J Physiol 1989; 256:E536-E542.

5. Magness RR, Rosenfeld CR. The role of steroid hormones in the control of uterine blood flow. In: The Uterine Circulation. Ithaca, NY: Perinatology Press; 1989; 10:239-271.

6. Osol G, Mandala M. Maternal uterine vascular remodeling during pregnancy. Physiology (Bethesda) 2009; 24:58-71.

7. Barker DJ. Intrauterine programming of adult disease. Mol Med Today 1995; 1:418-423.

8. Romero R, Dey SK, Fisher SJ. Preterm labor: one syndrome, many causes. Science 2014; 345:760-765.

9. Rosenfeld CR, Cox BE, Roy T, Magness RR. Nitric oxide contributes to estrogen-induced vasodilation of the ovine uterine circulation. J Clin Invest 1996; 98:2158-2166.

10. Gokina NI, Kuzina OY, Vance AM. Augmented EDHF signaling in rat uteroplacental vasculature during late pregnancy. Am J Physiol Heart Circ Physiol 2010; 299:H1642-H1652.

11. Ni Y, May V, Braas K, Osol G. Pregnancy augments uteroplacental vascular endothelial growth factor gene expression and vasodilator effects. Am J Physiol 1997; 273:H938-H944.

12. Chen DB, Jia S, King AG, Barker A, Li SM, Mata-Greenwood E, Zheng J, Magness RR. Global protein expression profiling underlines reciprocal regulation of caveolin 1 and endothelial nitric oxide synthase expression in ovariectomized sheep uterine artery by estrogen/progesterone replacement therapy. Biol Reprod 2006; 74:832-838.

13. Chen DB, Bird IM, Zheng J, Magness RR. Membrane estrogen receptordependent extracellular signal-regulated kinase pathway mediates acute activation of endothelial nitric oxide synthase by estrogen in uterine artery endothelial cells. Endocrinology 2004; 145:113-125.

14. van der Heijden OW, Essers YP, Fazzi G, Peeters LL, De Mey JG, van Eys GJ. Uterine artery remodeling and reproductive performance are impaired in endothelial nitric oxide synthase-deficient mice. Biol Reprod 2005; 72:1161-1168.

15. Kulandavelu S, Whiteley KJ, Qu D, Mu J, Bainbridge SA, Adamson SL. Endothelial nitric oxide synthase deficiency reduces uterine blood flow, spiral artery elongation, and placental oxygenation in pregnant mice. $\mathrm{Hy}$ pertension 2012; 60:231-238.

16. Rosenfeld CR, Roy T. Prolonged uterine artery nitric oxide synthase inhibition modestly alters basal uteroplacental vasodilation in the last third of ovine pregnancy. Am J Physiol Heart Circ Physiol 2014; 307:H1196H1203.

17. Wang R. Physiological implications of hydrogen sulfide: a whiff exploration that blossomed. Physiol Rev 2012; 92:791-896.

18. Leffler CW, Parfenova H, Basuroy S, Jaggar JH, Umstot ES, Fedinec AL. Hydrogen sulfide and cerebral microvascular tone in newborn pigs. Am J Physiol Heart Circ Physiol 2011; 300:H440-H447.

19. Bhatia M. Hydrogen sulfide as a vasodilator. IUBMB Life 2005; 57:603606.

20. Yang G, Wu L, Jiang B, Yang W, Qi J, Cao K, Meng Q, Mustafa AK, $\mathrm{Mu}$ W, Zhang S, Snyder SH, Wang R. H2S as a physiologic vasorelaxant: hypertension in mice with deletion of cystathionine gamma-lyase. Science 2008; 322:587-590.

21. Zhao W, Zhang J, Lu Y, Wang R. The vasorelaxant effect of $\mathrm{H} 2 \mathrm{~S}$ as a novel endogenous gaseous KATP channel opener. EMBO J 2001; 20:60086016.

22. Li Y, Zang Y, Fu S, Zhang H, Gao L, Li J. H2S relaxes vas deferens smooth muscle by modulating the large conductance $\mathrm{Ca} 2+$-activated $\mathrm{K}+$ (BKCa) channels via a redox mechanism. J Sex Med 2012; 9:2806-2813.

23. Sheibani L, Lechuga TJ, Zhang HH, Hameed A, Wing DA, Kumar S, Rosenfeld CR, Chen DB. Augmented H2S production via CBS upregulation plays a role in pregnancy-associated uterine vasodilation. Biol Reprod 2017; 96:664-672.

24. Cindrova-Davies T, Herrera EA, Niu Y, Kingdom J, Giussani DA, Burton GJ. Reduced cystathionine gamma-lyase and increased miR-21 expression are associated with increased vascular resistance in growth-restricted pregnancies: hydrogen sulfide as a placental vasodilator. Am J Pathol 2013; 182:1448-1458.

25. Wang K, Ahmad S, Cai M, Rennie J, Fujisawa T, Crispi F, Baily J, Miller MR, Cudmore M, Hadoke PW, Wang R, Gratacos E et al. Dysregulation of hydrogen sulfide producing enzyme cystathionine gammalyase contributes to maternal hypertension and placental abnormalities in preeclampsia. Circulation 2013; 127:2514-2522.

26. Lechuga TJ, Zhang HH, Sheibani L, Karim M, Jia J, Magness RR, Rosenfeld CR, Chen DB. Estrogen replacement therapy in ovariectomized nonpregnant ewes stimulates uterine artery hydrogen sulfide biosynthesis by selectively up-regulating cystathionine beta-synthase expression. Endocrinology 2015; 156:2288-2298.

27. Schultz JR, Petz LN, Nardulli AM. Cell- and ligand-specific regulation of promoters containing activator protein- 1 and $\mathrm{Sp} 1$ sites by estrogen receptors alpha and beta. J Biol Chem 2005; 280:347-354.

28. Mendelsohn ME. Genomic and nongenomic effects of estrogen in the vasculature. Am J Cardiol 2002; 90:F3-F6.

29. Liao WX, Magness RR, Chen DB. Expression of estrogen receptors-alpha and -beta in the pregnant ovine uterine artery endothelial cells in vivo and in vitro. Biol Reprod 2005; 72:530-537.

30. Martini PG, Katzenellenbogen BS. Modulation of estrogen receptor activity by selective coregulators. J Steroid Biochem Mol Biol 2003; 85:117122.

31. Magness RR, Phernetton TM, Gibson TC, Chen DB. Uterine blood flow responses to ICI 182780 in ovariectomized oestradiol-17beta-treated, intact follicular and pregnant sheep. J Physiol 2005; 565:71-83.

32. Zhang HH, Feng L, Wang W, Magness RR, Chen DB. Estrogen-responsive nitroso-proteome in uterine artery endothelial cells: role of endothelial nitric oxide synthase and estrogen receptor-beta. J Cell Physiol 2012; 227:146-159.

33. Mata-Greenwood E, Liao WX, Wang W, Zheng J, Chen DB. Activation of AP-1 transcription factors differentiates FGF2 and vascular endothelial growth factor regulation of endothelial nitric-oxide synthase expression in placental artery endothelial cells. J Biol Chem 2010; 285:17348-17358.

34. Hurst AG, Goad DW, Mohan M, Malayer JR. Independent downstream gene expression profiles in the presence of estrogen receptor alpha or beta. Biol Reprod 2004; 71:1252-1261.

35. Gibson TC, Phernetton TM, Wiltbank MC, Magness RR. Development and use of an ovarian synchronization model to study the effects of endogenous estrogen and nitric oxide on uterine blood flow during ovarian cycles in sheep. Biol Reprod 2004; 70:1886-1894.

36. Dawood MY, Ratnam SS. Serum unconjugated estradiol-17 beta in normal pregnancy measured by radioimmunoassay. Obstet Gynecol 1974; 44:194-199.

37. Byers MJ, Zangl A, Phernetton TM, Lopez G, Chen DB, Magness RR. Endothelial vasodilator production by ovine uterine and systemic arteries: ovarian steroid and pregnancy control of ERalpha and ERbeta levels. J Physiol 2005; 565:85-99.

38. Hewitt SC, Li Y, Li L, Korach KS. Estrogen-mediated regulation of Igf1 transcription and uterine growth involves direct binding of estrogen receptor alpha to estrogen-responsive elements. J Biol Chem 2010; 285:26762685 
39. Si H, Yu J, Jiang H, Lum H, Liu D. Phytoestrogen genistein up-regulates endothelial nitric oxide synthase expression via activation of cAMP response element-binding protein in human aortic endothelial cells. Endocrinology 2012; 153:3190-3198.

40. Su EJ, Lin ZH, Zeine R, Yin P, Reierstad S, Innes JE, Bulun SE. Estrogen receptor-beta mediates cyclooxygenase- 2 expression and vascular prostanoid levels in human placental villous endothelial cells. Am J Obstet Gynecol 2009; 200:427.e1-427.e8 e421-428.

41. Li H, Mani S, Cao W, Yang G, Lai C, Wu L, Wang R. Interaction of hydrogen sulfide and estrogen on the proliferation of vascular smooth muscle cells. PLoS One 2012; 7:1-10.

42. Ge Y, Konrad MA, Matherly LH, Taub JW. Transcriptional regulation of the human cystathionine beta-synthase $-1 \mathrm{~b}$ basal promoter: synergistic transactivation by transcription factors NF-Y and Sp1/Sp3. Biochem J 2001; 357:97-105.

43. Yang G, Pei Y, Teng H, Cao Q, Wang R. Specificity protein-1 as a critical regulator of human cystathionine gamma-lyase in smooth muscle cells. J Biol Chem 2011; 286:26450-26460.

44. Kraus JP, Oliveriusova J, Sokolova J, Kraus E, Vlcek C, de Franchis R, Maclean KN, Bao L, Bukovsk, Patterson D, Paces V, Ansorge W et al. The human cystathionine beta-synthase (CBS) gene: complete sequence, alternative splicing, and polymorphisms. Genomics 1998; 52:312-324.
45. Yin P, Zhao C, Li Z, Mei C, Yao W, Liu Y, Li N, Qi J, Wang L, Shi Y, Qiu S, Fan J et al. Sp1 is involved in regulation of cystathionine gamma-lyase gene expression and biological function by PI3K/Akt pathway in human hepatocellular carcinoma cell lines. Cell Signal 2012; 24 : 1229-1240.

46. Meyer MR, Prossnitz ER, Barton M. The G protein-coupled estrogen receptor GPER/GPR30 as a regulator of cardiovascular function. Vasc Pharmacol 2011; 55:17-25.

47. Pedram A, Razandi M, Aitkenhead M, Hughes CC, Levin ER. Integration of the non-genomic and genomic actions of estrogen. Membrane-initiated signaling by steroid to transcription and cell biology. J Biol Chem 2002; 277:50768-50775.

48. Tropea T, De Francesco EM, Rigiracciolo D, Maggiolini M, Wareing M, Osol G, Mandala M. Pregnancy augments G protein estrogen receptor (GPER) induced vasodilation in rat uterine arteries via the nitric oxide cGMP signaling pathway. PLoS One 2015; 10:e0141997.

49. Haynes MP, Sinha D, Russell KS, Collinge M, Fulton D, Morales-Ruiz M, Sessa WC, Bender JR. Membrane estrogen receptor engagement activates endothelial nitric oxide synthase via the PI3-kinase-Akt pathway in human endothelial cells. Circ Res 2000; 87:677-682.

50. Murphy E. Estrogen signaling and cardiovascular disease. Circ Res 2011; 109:687-696. 